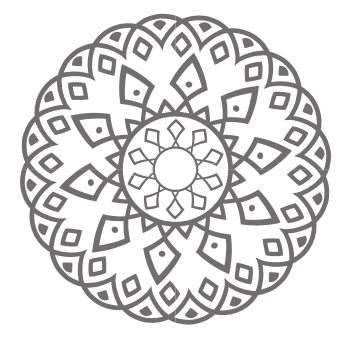

\title{
Modern Technology Urgency in the DEVELOPMENT OF ISLAMIC LAW
}

\author{
Salman Maggalatung
}

\begin{abstract}
This paper aims at examining the advancement of modern technology and its intersection with Islamic law. Some areas discussed are related to worship, family law, and medical treatment using organ transplantation. This study finds that some areas of Islamic law are statics, while others are dynamics. The modern technology has provided convenience for human beings such as the use of technology in pilgrimage; the determination of paternity; having baby through IVF, and the medical treatment for patients with heart failure. On the other hand, modern technology cannot change Islamic provisions on worship.
\end{abstract}

Keywords: Islamic law; modern technology; worship 
Abstrak: Kemajuan teknologi modern telah mengarah pada persilangannya dengan hukum Islam, termasuk di bidang ibadah, hukum keluarga, dan perawatan medis seperti penggunakan transplantasi organ. Beberapa bidang hukum Islam bersifat statis sementara yang lain bersifat dinamis. Teknologi modern telah memberikan kemudahan bagi manusia seperti penggunaan teknologi dalam berhaji; penentuan ayah terhadap bayi melalui IVF, dan perawatan medis untuk pasien dengan gagal jantung. Di sisi lain, teknologi modern tidak dapat mengubah ketentuan Islam tentang ibadah.

Kata kunci: hukum Islam; teknologi modern; ibadah 


\section{Introduction}

Islamic law comes from the Quran and hadith. Therefore, Islamic law is fixed (static) in some cases, and also flexible (dynamic). The static Islamic law is especially on matters related to the qati proposition such as the number of five prayer times; the caning of young adulterers; the death penalty for murderers of fellow believers; and so forth. Meanwhile, the dynamic Islamic law is derived for the Zanni proposition such as the mandatory and non-mandatory of reading al-Fatihah; the prohibition of bank interest; the pregnancy period, etc. Thus, the static Islamic law cannot be changed according to time and spice, while the dynamic Islamic law is changed with the changes of time and space. Ibn Qayyim al-Jauzi (without years: 3 ) argued that Islamic law changes along with the changing of times, places, conditions, intentions and customs.

In line with the above explanation, it is also crucial to examine the relationship between Islamic law, both static and dynamic, with the advancement of technology. An example of the relationship between modern technology and Islamic law can be seen in the case of aircraft technology and the practice of fasting. For instance, a fasting person flies from Jakarta at 13.00 Eastern Indonesia Time to Ambon and arrives in Ambon by the time of breaking fast at 18.45 EIT. At that time, the time in Jakarta is still at 16.45 West Indonesia Time. The question then, is the person allowed to break the fast by following the area where he is at? Or, should he follow the Jakarta time where he started his fasting?

Another example is in the case of anti-menstrual pills for women pilgrims. Currently, women can use anti-menstrual pills during Hajj to prevent menstruation so that they can optimize their worshipping activities during the pilgrimage. The question after that is: what is the legal status of the anti-menstrual pills used during Hajj? Is it allowable to prevent menstruation and to optimize the pilgrimage activities? These two cases show that technological progress can be tangent with mahdah (vertical dimension) worships. It shows that modern technological progress can be tangent to the implementation of mahdah worship.

Modern technological advancement also comes in contact with Islamic family law. Telecommunication technology, such as telephones 
enable marriage contracts by telephone. In the case of medical technology, postpartum pills have been used by women during the iddah period. Furthermore, infant tube technology helps couples to have children through natural conception. (La Jamaa, 2017: 49).

Nevertheless, the use of IVF has been considered to contradict with maqasid al-shariah (Syatibi, 2003: 10), especially the maintenance of offspring (hifz al-nasl). Even modern technology has enabled the use of a rented uterus. So, can a woman's womb be rented to conceive another couple's fetus?

Based on the above issues, this paper will analyze the interlocking between Islamic law with modern technology progress. According to Duski Ibrahim (2008: 233), which represents the view of the first generation, Islamic law has a dynamic characteristic. With this dynamic, Islamic law is able to solve various problems that occur in society. Issues discussed in this paper are limited to the matters around fasting, hajj, Islamic family law, and a medical issue.

\section{Fasting and Hajj Fasting}

Fasting means restraint (al-imsak) from material and non-material desires. Terminologically, fasting is restraint from everything that can break the fasting (i.e. eating, drinking and sexual relationship of husband and wife) from the dawn to sunset with the intention for the sake of Allah (Mujib, 2007: 201).

Based on the above definition, it can be understood that fasting takes place from siddiq dawn to sunset. This shows the period of fasting. In the case of Indonesia, the average fasting period is over 10 hours. Fasting is a mahdah (vertical) worship that has been determined by the sharia. Fasting should be done in the way that was exemplified by the Prophet Muhammad. Therefore, the period of fasting is as stipulated by the sharia. Imsak or the beginning of fasting is since the siddiq dawn, while the breaking fast time is after sunset. This is in accordance with the provision of the Quran in Sura al-Baqarah: 187.

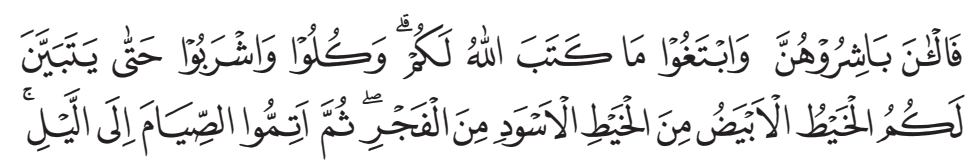


"So now mix them up and follow what Allah has ordained for you, and Eat drink to the light you are white from the black thread of dawn. then complete the fast until (coming) night" (Ministry of Religious Affairs, 2009: 36).

With relation to the progress of technology, the problem arises when someone travels to a region in a different time zone from his/ her departure city. For example, someone travels by plane from the western part of Indonesia to the eastern part of Indonesia. The period of these two regions is two hours. The question is: which time should this person follow to break the fasting?

In this case, people can break the fasting according to the local time of their destination, which in the above case is the eastern Indonesia time. Likewise, this applies to those who travel otherwise. People who travel from eastern Indonesia to western Indonesia will break the fasting according to the sunset of the local time. So, the need to wait until the sunset in western Indonesia.

From the above discussion, it can be seen that modern transportation, although cursory, can change the time of fasting by speeding it or slowing it. The difference in time fasting time caused by the use of air transportation is more caused by the necessity to follow the sun circulation in the destination region.

A more serious problem arises in long distance travelling. For instance, some travels from Indonesia to the United States. The time difference between Jakarta and Washington is eleven hours. People may experience a longer fasting period. Similar to the above explanation that people should follow the fast-breaking time in the local region where they are. Those who travel from Jakarta to Washington will have longer fasting time because they need to wait for the dusk in Washington. Conversely, those who travel from Washington to Jakarta will have shorter fasting time, but they can break the fast according to Jakarta time, as their destination.

Another impact of technology on fasting is regarding menstrual suppression. The question is as follow: Are Muslim women allowed to use medication to suppress their menstrual period in order to have one full fasting month? Muslim scholars have a consensus that women are prohibited to fast during their menstrual period. Islamic law requires women to make the fasting days they missed outside Ramadan month. 
In this case, women do not need any menstrual suppression pills, and they can undergo fasting naturally.

However, if there are women who consider the importance of using medication to delay their menstrual period, then it is permissible to use the medication, provided that the use of the menstrual suppression medication has no negative implications (Utomo, 2003: 243; Qardhawi 1995: 420). The use of menstrual suppression medication should consider the benefits of its users, especially from the medical side.

\section{Hajj}

Hajj means deliberating (al-qasd) on something that is glorified. Terminologically, the pilgrims, intend to go to the Ka'bah (Baitullah); possess the conditions (of being Muslims, adults, intelligent, independent, and capable); and perform the principle of Hajj (ihram in miqat, wuqf in Arafah, tawaf ifadha, sa'i, ihram in miqat, staying at muzdalifa, staying in meena, throwing jumrah, and tawaf wada) at the appointed time (Shawwal, Dzul Qa'dah, and Dzul Hijjah) (Mujib, 2007: 295).

In performing tawaf ifadhah, Muslims need to be clean from any impurity (najasah) such as menstruation. Women cannot perform tawaf ifadhah during menstruation. The question, after that, can women use the menstrual suppression pills before performing tawaf ifadhah?

Menstruation is closely related to mahdah worship, considering that it is prohibited for a woman to perform prayers, fasting and tawaf during their period. On the other hand, the menstrual delay pill is related to the worldly matter. In this matter, the use of menstrual delay pills is prohibited if there is a provision that prohibit it. There is no clear proposition that prohibits the use of menstrual pills (Aspandi, 2016: 4).

Menstruation is a natural phenomenon experienced by women during their fertile periods (Brantalid et al., 2104: 600). Hence, women should allow menstruation to occur naturally. The use of menstrual delay pills should be under the supervision of medical experts, which in this case by obstetricians, in order not to cause any harm to women's reproduction. Although permissible for the sake of performing tawaf ifadha, women should stop using the medication after carrying out 
the tawaf ifadhah. The use of the pills is merely as a dispensation to obliterate the obstacle in Hajj. In this matter, fiqh principle applied is: maa jaaza li'udzrin bathala bizawaalihi (what is allowed because of obstacles is not allowed anymore with the loss of the obstacles) (A. Djazuli, 2006: 62).

Accordingly, the existence of menstrual delay pills is only suitable for the presence of difficulties (mashaqqah). The treatment should not be exploited under normal conditions. Moreover, the pills function to change the menstrual cycle, which potentially causes medical side effects on women's reproductive health.

\section{Family Law}

\section{Marriage Contract over the Phone}

There are five pillars of marriage, namely (1) the presence of the bridegroom; (2) the existence of the bride; (3) the guardian of the bride; (4) two fair witnesses; and (5) the marriage contract (qabul). Marriage will be considered valid if the five pillars of marriage are completely fulfilled. The marriage will not be valid with the absence of one of the pillars. The marriage contract is based on the principle of willingness. Because the willingness is abstract (not visible), then it is manifested in the form of ijab qabul (marriage contract). Thus, the marriage contract becomes one of the pillars of marriage (Zein, 2004: 2).

In particular condition, the marriage contract can be facilitated by telephone. This happens due to the inability of the groom or guardian to be present in the ceremony. In this situation, the question arises: is the use of the phone in the marriage contract legitimate or valid?

The debate around the validity of the marriage contract by telephone is closely related to the requirement of being present in one place of ijab (proposal) and qabul (acceptance). Satria Effendi M. Zein (2004: 3) quotes al-Jaziri, stating that the mujtahid scholars agreed to the requirement of the marriage contract in one sitting or one gathering. Consequently, if the proposal and acceptance are not done simultaneously with the acceptance, then the marriage contract is considered invalid. With regards to requirement to be in one sitting in carrying out the marriage contract, there are two opinions arise.

Fist, the meaning of one sitting in the marriage contract is that 
the proposal and acceptance should be made within the time span of a marriage contract without time intervals. Thus, 'one sitting' concerns with the necessity of time lapse between the ijab and qabul, and not with the unity of place. Therefore, if the marriage contract is carried out in one place but different time, then the contract is not achievable. Conversely, the marriage contract can be done not in one place, but there should be no interruption between the proposal and the acceptance.

Second, the marriage contract in one sitting is required not only to ensure the continuity between ijab and qabul, but also to ensure that the witnesses see with their bare eyes that the ijab and qabul are declared by the respective parties.

The first point of view implies the validity of the marriage contract over telephone. Even though the marriage contract is carried out in different places, the ijab is carried out by the bride's guardian with the presence of witnesses, while the groom makes the qabul in another place with the present of non-formal witness. The formal witnesses directly see and listen to the bride's guardian expresses a favor and consent. Likewise, the non-formal witness also witnesses the same thing, by seeing the groom pronouncing the qabul and listening to the bride's guardian expressing a favor. The second opinion, on the other hand, implies that the marriage contract over a phone is not legitimate; for both witnesses cannot see the groom directly pronounces the qabul.

Both opinions illustrate that the current technological advancement in communication has been able to eliminate doubts about the authenticity of the groom's voice when pronouncing the qabul. Moreover, the presence of mobile phones with Android 3T application has enabled the live images of both parties in the mobile phone screens.

\section{Iddah Period}

Etymologically iddah comes from the Arabic verb 'adda-ya'uddu, which means counting or something is counted. Terminologically, iddah is a time to wait for the sanctity of a newly divorced woman or a woman whose husband just passed away. Before the period ends, she is forbidden to marry another man (Yanggo and AZ, 1999: 149). The determination of the iddah period is based on her menstrual cycle. 
Considering the existence of menstrual delay pills, the question then: can the pills be used to change the legal provision of the iddah period?

Observing the function of the menstrual suppression pills, it can be argued that the medication cannot be used to determine the short length of the iddah period. Similarly, the presences of Ultra Sound Gxxx (USG), which can detect the possibility of pregnancy, cannot eliminate the provision of the iddah period. This provision is considered the wisdom of Islamic law. One example is that the iddah period provides time and opportunity for the divorcee to reconcile (Yanggo, 2005: 175176). Although the provisions of iddah in Islamic law have a human dimension (rational or ta'aqulli), the dominant dimension is the Divine dimension (ta'abbudi). Consequently, the provision of the iddah period cannot be altered with the use of technology. The notion of iddah should be obeyed as a part of faith in God.

Another case is related to the technology of DNA testing. This technology can be used to solve the problem of paternity (Tamimi, 2014: 95). For example, in the case of the parents' doubt over their child, DNA testing can be a solution. This is because the paternity status has significant consequences on a child's education, marriage, and inheritance. For example, a woman needs their biological father to be able to marry a man. In inheritance, one cannot receive any inheritance without the paternity relationship.

\section{Test-tube Baby}

The presence of children in the household often becomes the dream of each married couple. The failure of getting a child through a natural pregnancy can be a source of conflict between a husband and wife. In the modern world, this problem has been overcome by test-tube baby technology or In Vitro Fertilization technology. It is crucial to examine the practice of test-tube baby according to Islamic Law.

Test-tube baby in the medical world is known as artificial insemination. Artificial means "human-made". Meanwhile, insemination is derived from a Latin word inseminatus, which means "income or delivery". Artificial insemination means "artificial conception" (Hasan, 2000: 70). Terminologically, artificial insemination is an attempt of conception in the uterus to get offspring without a natural conception 
process. Artificial insemination in human is done by taking sperm to be injected into a woman's uterus. This woman can be the wife of the sperm owner or another woman (Dahlan, 2003: 727). Thus, the testtube baby is a reproduction attempt using artificial uterus that allows the occurrence of conception outside the uterus through the process of In Vitro Fertilization. This process is carried out by taking sperm and ovum from a couple to be proceeded in a vitro (tube). After the conception, the embryo is transferred into the womb of the wife (Dahlan, 2003: 729-730).

To determine the law of test-tube baby, it is crucial to examine this practice by investigating the source of sperm and ovum, and the owner of the uterus. The allowed practice of the IVF in Islam is when the sperm comes from the husband, and the ovum comes from the wife. The fertilized embryo is then transferred into the womb of the wife. In this case, artificial insemination is different from natural conception. The permissibility of this practice based on the consideration that the child is the descendant of the couple.

The rule of Islamic law affirms:

$$
\text { الحجة تنز يل منزلة الضرورة و الضرورة تبيح المخظورات }
$$

Hajat (a very important requirement) is treated as in an emergency whereas an emergency is forced to do things that are forbidden (Zuhdi, 1997: 21-22).

The existence of the source of seeds (sperm and ovum) and the womb is very crucial because they play a significant role in maintaining offspring that becomes one of the elements in maqasid al-syariah. Therefore, if the source of the seeds is unknown or the womb is not the wife's, then the test-tube baby is haram (prohibited). The use of a rented uterus is haram (prohibited) even though the seeds come from a legitimate husband and wife. Likewise, it is also prohibited to use sperm or ovum from donors, even though the embryo is developed in the womb of the wife. This is based on the hadith of the Holy Prophet:

$$
\begin{aligned}
& \text { لا يحل لإمرئ يؤمن با لله و اليوم الآخر ان يسقي ماءه زرع غيره (رواه أبو } \\
& \text { داود عن رويفع بن ثابت) }
\end{aligned}
$$

It is not lawful for a man to believe in Allah and the last day to sprinkle his water (sperm) into the plant (womb of the wife) of others. (Abu Dawud from Ruwaifa bin Sabit) (Abu Daud: 1990: 478) 
This Hadith not only implies the pouring of sperm into the womb of a woman through sexual intercourse but also illustrate the practice of inserting sperm to a womb of a woman, who has no marital relationship, through the process test-tube baby. In Islam, the relationship between a husband and wife, also, to enjoying the blessing of God in channelling sexual desires, also aims to obtain offspring. Therefore, the sperm of a husband can only be channelled into the womb of his legitimate wife.

The prohibition of the use of sperm and ovum from donors and insert the seeds to a rented uterus is based on the principle of Islamic law, namely dar'u al-mafasidi muqaddamun 'ala jalbi al-masalihi'. This means avoiding damages is prioritized rather than achieving goods'(Djazuli, 2006: 11). In this case, the benefit of the test-tube baby program using seeds from a donor is to help the couple to get a child. However, the mafsadah (cost) caused by this method is far greater than the benefits, among others: (1) the mixing of offspring, whereas Islam greatly maintains the sanctity of honor and purity offspring, because it relates to tranquillity and inheritance; (2) the method is against sunnatullah or the law of Allah; (3) the mixing of sperm and ovum without a legal marriage is similar to adultery; (4) the child born in the IVF potentially becomes a source of conflict within the household; (5) children born through IVF without clear information about the donor is worse than the adopted children with known origin (Utomo, 2003: 190-191).

Children born through IVF that use donor sperms or ovum are similar to children resulted from adultery. Thus, the difficulty in having a child through a natural pregnancy cannot legalize the use of sperm and ovum from donors; or the use of rental womb. Children born with the involvement of donor are categorized as illegitimate children. Therefore, they have the only relationship with the mother who gave birth to them.

In addition, IVF technology should not be abused by selecting a specific gene that has desired intelligence, skin color, or other physical properties. This is because the life of the fetus needs to be protected by the law (Aksoy, 2005: 400). Based on the above description, it can be argued that the prohibition of using seeds from donors and the rental womb is related to the existence of the child. This is to avoid legal and social problems in matters related to marriage, inheritance, and social 
status in society. Children adoption is a better option than the wrong use of IVF technology.

\section{Pig Organ Transplant to Human}

In general, the aim of organ transplants is to replace the organs that are no longer work properly. Among the organs are kidney, heart and cornea. One type of transplantation is heterotransplantation, which means that the organ comes from animals to be transplanted to a human's body. For example, a pig's heart valve is transplanted to replace a human's heart (Abu Yasid, 2005: 220). The use of pig's heart valves for humans is problematic because pigs are regarded as impure animals as is mention in the Quran, Sura Al-Maidah: 3.

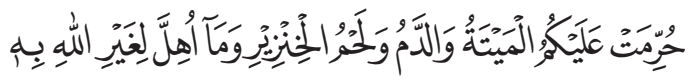

'Forbidden to you (eat) carcasses, blood, pork, (meat) of animals slaughtered not on (name) Allah' (Ministry of Religious Affairs of the Republic of Indonesia, 2009: 142)

The prohibition of pigs in this verse is general, whether it is related to the prohibition to eat the meats or to use the organs for other purposes. Medical technology allows the use of pig heats transplants into the human body. In Islam, this is permissible if the attempt to find a human organ donor has failed (Abu Yasid, 2005: 224). This skill is based on the consideration that a person's heart failure (recipient) function is very threatening to the safety of his life. Thus, the recipient has been in an emergency condition. This emergency condition allows things that are prohibited in Islamic law (al-dlaruratu tubibu almahzhurat) (Djazuli, 2006: 72).

In the case of pig's heart valve, it is God's right, so His creatures can be used in times of emergency. Using human's organ without permission from the donor is also not allowed or haram. The permission from the donor is crucial in organ transplantation. Advances are modern medical technology, especially organ transplant technology, can be utilized for the benefit of human life while maintaining the provisions of Islamic law in the field of medicine. In this regards, it is necessary to consider the impact of pig heart valve transplant to avoid any harms for the recipient, as it may have serious side effects on him/her (Stewart et al., 2003: 2105-2106). 


\section{Conclusion}

Based on the above discussion, it can be concluded that modern technological advances can be tangent to various aspects of Islamic law, including worship (fasting, pilgrimage), family law (iddah, baby tube) and medical issues (organ transplants). Advances in transportation technology facilitate the transfer of people from one region to another. During the fast time in the Ramadan month, the time of breaking fast may be an issue for travellers using advance transportation. In this case, the travellers follow the time of their destination to break their fast.

In the case of menstrual suppression pill, it can be used in hajj to optimize the rituals performed during the pilgrimage. However, this is not applicable for Ramadan fasting or iddah period. Women should not use the pills during that time. Moreover, another medical technology such as ultrasound to check women's womb cannot change the iddah period as is determined by Islamic law.

Islamic law allows married couples, who fail to get a child through a natural pregnancy, to use infant tube technology with the sperm of the husband and the ovum from the wife. Then, the embryo is transferred into the womb of the wife. Conversely, it is unlawful to use sperms or ovum from a donor and to use another woman's uterus or rented uterus. For the case of heart failure, the use of a pig heart valve is allowable as long as a human's donor is unfound.

Those cases show that the advancement in medical technology can be useful to facilitate religious purposes. These include the pilgrimage rituals, the desire to have offspring through natural means, and to save people's life suffered from heart failures.

\section{References}

Abu Daud.Sunan Abud Daud, Volume 1, Beirut: Dar al-Fikr, 1990.

Aksoy, S. "Making Regulations and Drawing up Legislation in Islamic Countries under Conditions of Uncertainty, with Special Reference to Embryonic Stem Cell Research, "Journal of Medical Ethics, June 2005.

Aspandi. "Pemakaian Obat Siklus Haid Bagi Jamaah Haji Indonesia Telaah Kaidah Al-Masyaqqatu Tajlibu al-Taysir," Jurnal Syariah dan Hukum (AlAdalah), Vol. 1, No. 1, 2016.

Brantelid, Ida Emilie, et al. "Menstruation During a Lifespan: A Qualitative Study of Women's Experiences," Health Care for Women International, 30 January 2014. 
Dahlan, Abdul Azisn, et al. (ed.). Ensiklopedi Hukum Islam, Volume 3, Jakarta: PT Ichtiar Baru van Hoeve, 2003.

Departemen Agama RI. Al-Qur'an dan Terjemahnya, Jakarta: Ditjen Bimas Islam, 2009.

Djazuli, A. Kaidah-Kaidah Fikih, Jakarta: Kencana, 2006.

Hasan, M. Ali. Masail Fiqhiyah al-Haditsah Pada Masalah-Masalah Kontemporer Hukum Islam, Jakarta: Raja Grafindo Persada, 2000

Ibrahim, Duski. Metode Penetapan Hukum Islam: Membongkar Konsep Al-Istiqra' al-Ma'nawi Asy-Syatibi, Jogyakarta: Ar-Ruzz Media, 2008.

Jamaa, La. Fiqih Kontemporer (Kajian Problematika Hukum Islam di Era Modern), Yogyakarta: Deepublish, 2017.

"Dimensi Ilahi dan Dimensi Insani dalam Maqasid al-Syariah," Jurnal AsySyir'ah, Vol. 45, No. II, Juli-Desember 2011.

Al-Jauziyah, Ibn Qayyim. I'lam al-Muwaqiin 'an Rabb al Alamin, Volume 3, Beirut: Dar al-Jail, t.th.

Mujib, Abdul. Kepribadian dalam Psikologi Islam, Jakarta: Raja Grafindo Persada, 2007.

Qardhawi, Yusuf. Hady al-Islami Fatawi Mu'asirah, translated by As'ad Yasin, Fatwa-Fatwa Kontemporer, Volume 1, Jakarta: Gema Insani Press, 1995.

Stewart, Kerry J., et al. "Cardiac Rehabilitation Following Percutaneous Revascularization, Heart Transplant, Heart Valve Surgery, and for Chronic Heart Failure," Chest Journal, Vol. 123, Issue 6, June 2003.

Al-Syatibi, Abu Ishaq ibn Musa. Al-Muwafaqat fi Usul al-Syariah, Volume 2, Beirut: Dar al-Kutub al-'Ilmiyyah, 2003.

Tamimi, Muh. “Tes DNA dalam Menetapkan Hubungan Nasab," Istinbath, Vol. 13, No. 1, Juni 2014.

Utomo, Setiawan Budi. Fiqih Aktual Jawaban Tuntas Masalah Kontemporer, Jakarta: Gema Insani Press, 2003.

Yanggo, Chuzaimah T., dan A. Hafizh Anshary. Problematika Hukum Islam Kontemporer, Book One, Jakarta: Pustaka Firdaus dan Lembaga Studi Islam dan Kemasyarakatan, 1995.

Yasid, Abu. Figh Realitas, Yogyakarta: Pustaka Pelajar, 2005.

Zein, Satria Effendi M. Problematika Hukum Keluarga Islam Kontemporer, Jakarta: Kencana, 2004.

Zuhdi, Masjfuk. Masail Fiqhiyah, Jakarta: PT Toko Gunung Agung, 1997.

Salman Maggalatung, Faculty of Sharia and Law, Syarif Hidayatullah State Islamic University Jakarta, Jalan H. Ir. Djuanda No. 95, Ciputat Tangsel.

E-mail: andisalmanm45@gmail.com 